\title{
What Are Basic Human Needs? A Challenge to the Self-Determination Theory in the SST Context
}

\author{
Larry Sau Kei Leung \\ Department of Marketing, Monash University, Melbourne, Australia \\ Email: larryskleung@gmail.com
}

How to cite this paper: Leung, L. S. K. (2019). What Are Basic Human Needs? A Challenge to the Self-Determination Theory in the SST Context. Psychology, 10, 958-976. https://doi.org/10.4236/psych.2019.107063

Received: December 23, 2018

Accepted: June 18, 2019

Published: June 21, 2019

Copyright $\odot 2019$ by author(s) and Scientific Research Publishing Inc. This work is licensed under the Creative Commons Attribution International License (CC BY 4.0).

http://creativecommons.org/licenses/by/4.0/ c) (i) Open Access

\begin{abstract}
Self-determination theory suggests that autonomy, competence and relatedness are the sole basic human needs that foster volitional forms of motivation. Given that perceived control, ease of use and usefulness have been found to enhance intrinsic motivation in the context of self-service technology (SST), it is argued that these later factors are also basic human needs that nurture volitional forms of motivation. Hence, it is hypothesized that the relationships between perceived control, ease of use and usefulness and the use of SSTs are mediated by self-determined motivation. Results suggest that self-determined motivation mediated the relationships between ease of use, usefulness and the use of SSTs but not the relationship between perceived control and the use of SSTs. Thus, basic human needs are not limited to autonomy, competence and relatedness; perceived ease of use and usefulness may also need to be included. Theoretical and managerial implications are also discussed.
\end{abstract}

\section{Keywords}

Basic Human Needs, Self-Determined Motivation, SSTs, Ease of Use, Usefulness, Autonomy, Competence, Relatedness

\section{Introduction}

Technology has radically changed the business landscape in recent years (Gallaugher, 2010). By using technology, organizations can reduce costs as well as increase access to, and exchange of, information (Parham, Roberts, \& Sun, 2001). Amongst different technologies, self-service technologies (SSTs) have attracted a great deal of attention from marketing academics and practitioners (Kelly, Lawlor, \& Mulvey, 2010). 
SSTs are defined as "technological interfaces that enable customers to produce a service independent of direct service employee involvement" (Meuter, Ostrom, Roundtree, \& Bitner, 2000: p. 50). Examples of SSTs include automated teller machines (ATMs), pay-at-the-pump machines, automated hotel and grocery store checkouts, telephone banking, airline check-in systems for e-ticket holders, in-store kiosks for product information, web-based purchasing, Internet transactions and supermarket self-checkout systems (Yang \& Klassen, 2008). As SSTs replace human-to-human contact with human-machine interaction (Parasuraman, 2000), consumers' perceptions of how services are conceived, developed and delivered have changed (Meuter, Bitner, Ostrom, \& Brown, 2005).

SSTs have become important contexts to further understand consumer motivation as customer's willingness to participate in using SSTs determines their successful deployment (Vargo \& Lusch, 2004; Mumani, Stone, \& Wang, 2018; Taillon \& Huhmann, 2019). Self-determination theory (SDT) has been used to understand consumers' motivations to use SSTs (Leung \& Matanda, 2013). It was found that basic human needs, such as autonomy, competence and relatedness, nurture volitional forms of motivation (Leung \& Matanda, 2013). To date, limited research has questioned the dimensions of basic human needs. The current study aims to further understand the dimensions of basic human needs and test self-determination theory. Managerial implications are also suggested.

\section{Theoretical Background}

Self-determination theory (SDT) posits that human's goals are achieved based on their psychological and cognitive responses to different levels of autonomy. According to SDT, different forms of motivation exist on a continuum (Deci \& Ryan, 1991; Ryan \& Connell, 1989).

Extrinsic motivation is regulated by different levels of autonomy or intra-psychic forces (Deci \& Ryan, 2000a, 2012; Ryan \& Connell, 1989). Extrinsic motivation comprises two forms of motivation: controlled and autonomous (Deci \& Ryan, 1985, 1991). When behavior is not regulated by intrinsic forces (e.g., a sense of volition), motivation can be considered autonomous or self-determined. When behavior is regulated by external forces (e.g., coerced interpersonal forces), motivation can be considered controlled or not self-determined (Deci \& Ryan, 2000b, 2012; Gagne \& Deci, 2005).

Controlled motivation comprises external and introjected regulations, and autonomous motivation comprises identified and integrated regulations (Deci \& Ryan, 1985, 2000b). External regulation is behavior that is regulated by intangible punishment or rewards (Deci \& Ryan, 2000b, 2012; Gagne \& Deci, 2005). Introjected regulation is behavior that is regulated by contingent consequences internal to individuals (Deci \& Ryan, 2000b, 2012). Identified regulation is present when the underlying value of an individual's behavior is accepted and recognized (Deci \& Ryan, 2000b; Gagne \& Deci, 2005). Integrated regulation is behavior that is internalized and fully integrated within one's self (Deci \& Ryan, 1985, 2000b, 2012). 
Extrinsic and intrinsic motivations are inter-related, as shown in Figure 1 (Deci \& Ryan, 2000a, 2012; Gagne \& Deci, 2005; Ryan \& Connell, 1989). Intrinsic motivation is behavior initiated for an individual's own sake (e.g., due to personal interests, for excitement). When extrinsic motivation is relatively autonomous, it is similar to intrinsic motivation (Deci \& Ryan, 1991). The type of motivation farthest from intrinsic motivation is a motivation, which refers to a lack of motivation.

Human behavior is driven when different forms of motivation are combined, which is referred to as self-determined motivation (Deci \& Ryan, 2000a, 2012; Gagne \& Deci, 2005). When motivation is self-determined, behavior is internalized (Deci \& Ryan, 2000b, 2012; Gagne \& Deci, 2005).

Empirical evidence suggests that self-determined motivation positively affects human well-being (Deci \& Ryan, 2008) and is important to students' learning, perceived competence, and school performance (Deci, Koestner, \& Ryan, 1999; Fortier, Vallerand, \& Guay, 1995; Vallerand et al., 1992, 1993). It also affects school principals' performance (Fernet, 2011), dental clinics' patient attendance (Halvari et al., 2010), and the use of information and communication technology (ICT) (Techatassanasoontorn \& Tanvisuth, 2008).

SDT suggests that a sense of volition drives human behavior and well-being (Deci \& Ryan, 2000a). Autonomy, competence, and relatedness are basic human needs that foster volitional forms of self-determined motivation, the process of internalization, and engagement in activities (Deci \& Ryan, 2000b, 2012). When extrinsic motivation is transformed into intrinsic motivation or the originally regulated motivation is assimilated into a personally endorsed value, it is referred to as the internalization process (Ryan, 1995).

Autonomy is defined as a situation "in which significant others offer choice, provide a meaningful rationale, minimize pressure, and acknowledge the target individual's feelings and perspectives" (Halvari, Halvari, Bjørnebekk, \& Deci, 2010). SDT proposes that controlling social contexts hinder internalization, whereas autonomous social contexts enhance internalization (Deci \& Ryan, 2000b). Self-determined and internalized behavior increases the likelihood that individuals will engage in uninteresting activities (Deci, Eghrari, Patrick, \& Leone, 1994; Deci \& Ryan, 2000a, 2012).

Competence or self-efficacy represents the degree to which an individual believes that he or she possesses the competence required to perform a task (Bandura, 1997). Individuals feel more effective and satisfied when engaging in activities

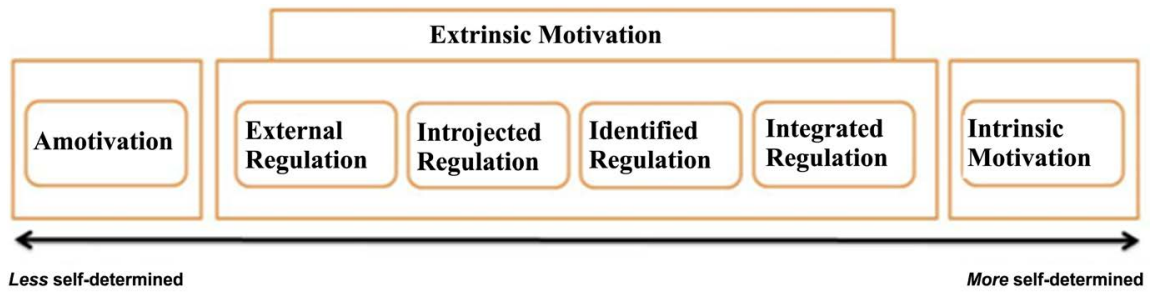

Figure 1. Continuum of motivations in SDT. 
in which they feel competent (Deci \& Ryan, 2000a), and therefore their behavior will be more internalized and self-determined (Deci \& Ryan, 2000a). The internalization process is also enhanced by relatedness, which can be defined as the need to feel connected to others or a sense of belonging (Deci \& Ryan, 2000a, 2000b, 2012). When individuals feel connected, their values are more internalized (Deci \& Ryan, 2000a, 2012).

Autonomy, competence and relatedness were found to drive self-determined motivation in different contexts (Halvari et al., 2010; Techatassanasoontorn \& Tanvisuth, 2008; Leung \& Matanda, 2013). To date, limited research has questioned the dimensions of basic human needs set by SDT. The current study argues that perceived control, ease of use and usefulness foster volitional forms of motivation and the use of SSTs. Therefore, these factors can be considered as basic human needs in the SST context and discussed in the following sections.

\section{Literature Review}

Ease of use. Customers tend to feel more satisfied when SSTs are easy to use (Meuter et al., 2000). When an innovation is easy to understand or use, it can be considered as possessing perceived ease of use (Zeithaml, Parasuraman, \& Malhotra, 2002). Perceived ease of use is the degree to which a person believes a particular system is free of effort (Davis, 1986). Perceived ease of use has positive effects on attitudes towards SSTs (Kim, Chun, \& Song, 2009; Lanseng \& Andreassen, 2007) and the usage of SSTs in different contexts (Guriting \& Ndubisi, 2006; Hernan-dez \& Mazzon, 2007; Wang, Wang, Lin, \& Tang, 2003; Venkatesh, 2000; Venkatesh \& Davis, 2000). In retailing, when consumers can easily handle technology, they exhibit positive attitudes towards SSTs (Rangarajan, Falk, \& Schillewaert, 2007). As attitudes towards SSTs are antecedents to the use of SSTs (Dabholkar \& Bagozzi, 2002; Wang \& Namen, 2004; Lee, Castellanos, \& Choi, 2012; Xie, Shen, \& Zheng, 2011), perceived ease of use will be used as a determinant of the use of SSTs in the current study.

Usefulness. When technology is easier to use, customers perceive technology to be more useful because they do not have to figure out how to use it and can complete their tasks more efficiently (Bruner \& Kumar, 2005). Perceived usefulness is defined as the subjective probability of using a technology to help a user complete a task (Eriksson, Bagozzi \& Warshaw, 2001; Guriting \& Ndubisi, 2006; Jaruwachirathanakul \& Fink, 2005; Laforet \& Li, 2005; Liao \& Cheung, 2002; Polatoglu \& Ekin, 2001). The usefulness of the SST service can positively affect users' continued use of Internet banking (Eriksson \& Nilsson, 2007). Perceived usefulness has different effects in different SST contexts (Curran \& Meuter, 2005). However, it can positively affect the use of SSTs in the retailing context (Lin \& Chang, 2011). Because consumers tend to choose services with more potential benefits, SSTs perceived to be useful attract more consumers to use them (Meuter et al., 2000; Parasuraman, Zeithaml, \& Malhotra, 2005).

Self-determined motivation. Self-determined motivation is important to the 
use of SSTs because it is related to the internalization process, which has a positive effect on an individual's engagement in activities (Deci \& Ryan, 2000b). Empirically, self-determined motivation enhances persistence (Teixeira et al., 2012), student competence and school performance (Fortier, Vallerand \& Guay, 1995; Deci, Koestner \& Ryan, 1999; Vallerand et al., 1992, 1993). Given that self-determined motivation has been identified as a mediator in different contexts, such as dental clinic attendance (Halvari et al., 2010), the use of ICT (Techatassanasoontorn \& Tanvisuth, 2008) and retailing SSTs (Leung \& Matanda, 2013), it can be considered a potential mediator of the use of SSTs in the current study.

\section{Justification of the Mediating Effect}

The justification of the mediating effects of self-determined motivation is based on the indirect effects of independent variables on dependent variables through the mediator (Judd \& Kenny, 2010; MacKinnon \& Luecken, 2008; MacKinnon et al., 2002; Shrout \& Bolger, 2002; Zhao, Lynch, \& Chen, 2010). In other words, based on empirical evidence, we argue that links are present between the independent variables, e.g. perceived control, ease of use, usefulness, and the mediator, e.g. self-determined motivation. We also argue that a link is present between the mediator, e.g. self-determined motivation and the dependent variable, e.g. the use of SSTs.

\section{Hypotheses and Conceptual Model}

As customers are more intrinsically motivated when they can customize their experience, perceived control has been shown to have a positive effect on intrinsic motivation (Collier \& Sherrell, 2010). Moreover, ease of use affects intrinsic motivation when options are more easily found and procedures are less ambiguous (Jaasma \& Koper, 1999; Sargeant \& Lee, 2004). Additionally, customers are more willing to learn how to use SSTs if they find the technology useful and advantageous (Meuter et al., 2005). Furthermore, self-determined motivation has a positive impact on the use of ICT (Techatassanasoontorn \& Tanvisuth, 2008) and SSTs (Leung \& Matanda, 2013). Considering these points, the direct effects of perceived control, ease of use and usefulness on self-determined motivation, and the direct effect of self-determined motivation on the use of SSTs are expected. Thus, the mediating effect of self-determined motivation on the relationship between perceived control, ease of use, usefulness, and the use of SSTs is inferred as depicted in Figure 2.

It is hypothesized that:

H1: Self-determined motivation mediates the relationship between perceived control and the use of SSTS.

H2: Self-determined motivation mediates the relationship between ease of use and the use of SSTs.

H3: Self-determined motivation mediates the relationship between usefulness and the use of SSTs. 


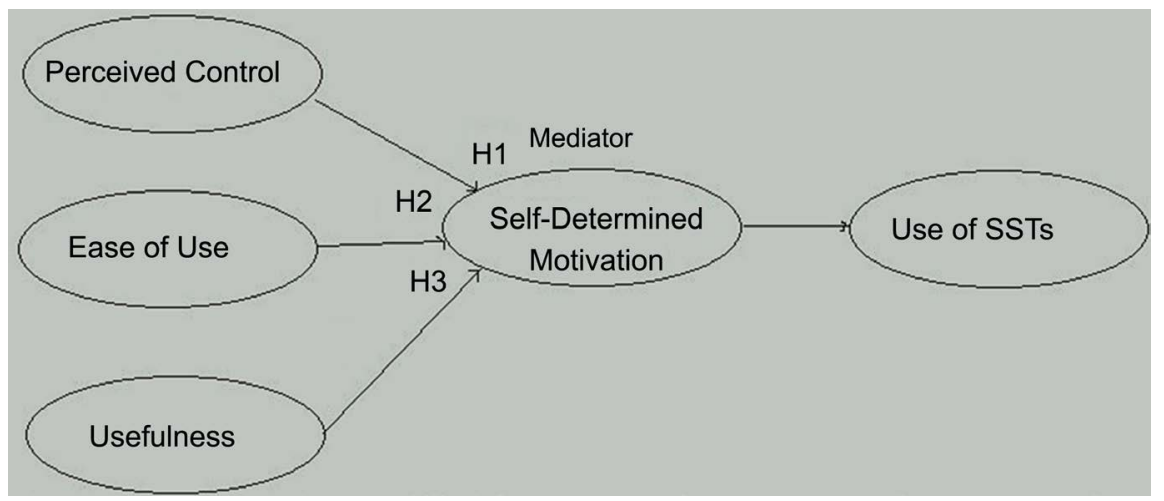

Figure 2. The conceptual model.

\section{Method}

\subsection{Sample and Procedure}

In the current study, a descriptive cross-sectional research design was used, because the major aim of the current study was to discover factors affecting the use of SSTs (Burns \& Bush, 2006). We administered the questionnaire using the online panel through Qualtrics. Australian shoppers over 18 years old and who had used supermarket self-checkout systems in the previous 12 months were invited to fill in the questionnaire. Prior to the study, the questionnaire was first evaluated by 10 Australian shoppers, 3 SST experts from Australian universities and 1 Australian supermarket manager. Three hundred and sixty one participants completed the questionnaires with no missing values for further analysis.

\subsection{Measures}

All constructs in the current study were measured with seven-point Likert scales (1 - 7) (1-strongly disagree, 7-strongly agree) as discussed below:

Perceived control. Dabholkar (1996), Yen and Gwinner (2003) and Zhu (2002) conceptualized perceived control as a uni-dimensional construct and defined it as the degree of individuals' desire to exhibit mastery over the environment. In the current study, the conceptualization of perceived control in five items used by Dabholkar (1996), Yen and Gwinner (2003) and Zhu (2002) was used.

Perceived ease of use. Ease of use is also viewed as the degree of complication and confusion of using the SST in library self-checkouts (Dabholkar \& Bagozzi, 2002; Zhao, Mattila, \& Tao, 2008). The measure of ease of use from Dabholkar and Bagozzi (2002) and Zhao, Mattila and Tao (2008) was adopted for the current study. Five measurement items were used to measure ease of use.

Usefulness. Weijters, Rangarajan and Falk (2005) measured usefulness as the efficiency, speed of shopping and waiting time associated with using self-scanning. The measure of perceived usefulness from Weijters, Rangarajan and Falk (2005) was adapted for the current study. Four measurement items were used to measure usefulness.

Self-determined motivation. Halvari et al.'s (2010) study examined five di- 
mensions: intrinsic motivation, integrated, identified, introjected and external motivation. The current study adopted Halvari et al.'s (2010) self-determination scale. Intrinsic motivation as well as integrated and introjected regulations was measured with five items, identified regulation was measured with six items and external regulation was operationalised as a seven-item measure.

The use of SSTs. Dabholkar and Bagozzi (2002) measured the use of SSTs as the likelihood or unlikelihood of an individual using the SST. Dabholkar and Bagozzi's (2002) study was adopted in the current study.

\section{Results}

\subsection{Purification of the Measurements}

The measurements were firstly purifying using exploratory factor analysis (EFA). The current study retained factors with eigenvalues greater than 1 (Hair, Black, Babin, \& Anderson, 2006) and with factor loading higher than or equal to .30 and with cross factor loadings $<.30$ (Field, 2000). After the analyses using oblique rotation method, 19 items and 4 dimensions (integrated regulation, introjected regulation, external regulation, \& intrinsic motivation) remained in self-determined motivation scale with Eigenvalues 7.27, 4.01, 3.35 and 6.85 . These items including items of perceived control, ease of use, usefulness and the use of SSTs were then evaluated by confirmatory factor analysis. Items removed according to the modification index resulted acceptable chi-square value $\left(\chi^{2}\right.$ $(224)=572.495, p<.001), \chi^{2} / \mathrm{df}=2.556, \mathrm{RMSEA}=.066, \mathrm{pclose}<.000, \mathrm{GFI}=.89$, $\mathrm{AGFI}=.85, \mathrm{NFI}=.93$ and $\mathrm{CFI}=.96(\mathrm{IFI}=.96, \mathrm{TLI}=.95)$. The correlation matrix of variables and demographic information can be found in Appendix A and

\section{Appendix B.}

\subsection{Testing the Reliability}

Reliability is the consistency of a set of measurements (Hair, Black, Babin, \& Anderson, 2010). Reliability was assessed using composite reliability (CR) and $p$-values of factor loadings in the current study (Zheng, 2006). The composite reliability of constructs in the current study ranged from .73 to .97 , which exceeded the acceptable level of .70 (Fornell \& Larcker, 1981). All factor loadings were also highly significant, with $p$-values less than or equal to .001. Therefore, all measures had sufficient consistency.

\subsection{Testing the Validity}

Validity refers to the ability of a measure to describe what it intends to measure (Haladyna, 1999). In validating the measurements for further analysis, the uni-dimensionality and convergent validity of constructs were tested (Steenkamp \& Van Trijp, 1991).

Uni-dimensionality. Uni-dimensionality can be assessed through estimating measurement models by model fits using CFA. A better model fit indicates a higher level of uni-dimensionality of the constructs in a scale (Hattie, 1985; An- 
derson \& Gerbing, 1988). The model fit indices suggested that the model was acceptable. Thus, the uni-dimensionality of constructs was established.

Convergent validity. Convergent validity is a measure of the convergence of items of a construct. Convergent validity can be assessed using the average variances extracted (AVEs) (Fornell \& Larker, 1981; Farrell \& Rudd, 2009) and the t-test for factor loadings (Anderson \& Gerbing, 1988). The AVEs of the constructs in the current study ranged from .47 to .90 . Because AVE is a more conservative test, AVEs above or close to the cut-off point of .5 indicated sufficient convergent validity (Batra \& Sinha, 2000). Additionally, all factor loadings were more than twice their standard errors and the t-values ranged from 2.98 to 13.08. Thus, the convergent validity of the constructs was acceptable.

\subsection{Validating the Simplex Structure of the Self-Determined Motivation Scale}

To quantify self-determined motivation, a relative autonomous index (RAI) formula was used, e.g. RAI $=$ external regulation $\times(-2)+$ introjected regulation $\times(-1)+$ integrated regulation $\times(+1)+$ intrinsic motivation $\times(+2)$ (Ryan \& Connell, 1989). Positive and negative relative autonomous indices represented high and low levels of self-determined motivation. The RAI was formed only if the correlations of different dimensions of self-determined motivation scale conformed to a simplex structure (Guttman, 1954). Li and Harmer (1996) proposed that when a simplex structure exists, the lower level of constructs should have stronger significant direct effects on the adjacent constructs than the indirect effects on distant constructs. The current study tested the existence of the simplex structure on self-determined motivation scale. The direct effects of each construct were added to its adjacent constructs to form an analytical model. This model, which was further analysed using SPSS AMOS 21 with maximum likelihood estimation (MLE), yielded a chi-square value $\left(\chi^{2}(34)=118.21, p<.001\right)$, $\chi^{2} / \mathrm{df}=2.32, \mathrm{RMSEA}=.06$, pclose $=.12$, GFI $=.95, \mathrm{AGFI}=.93, \mathrm{NFI}=.97$ and $\mathrm{CFI}=.98$. The results surpassed $\mathrm{Li}$ and Harmer's (1996) criteria that all direct effects to the adjacent constructs should be significant and all direct effects to the adjacent constructs were stronger than the indirect effects to more distant constructs. Thus, the continuum of motivation was assumed.

\subsection{Testing the Common Method Variance (CMV)}

The current research used the second lowest correlation as the unbiased proxy to evaluate the impact of CMV (Lindell \& Whitney, 2001; Sharma, Yetton, \& Crawford, 2010; Malhotra, 2006). As evident, the spurious correlation caused by CMV amounts from .00 to .02 , and all significant positive correlations between the predictors and the criterion (unadjusted $\mathrm{R}$ ) are above zero and remain significant (adjusted R) when the CMV is controlled. Sensitivity analysis also suggests that nearly all the positive correlations between the predictors and the criterion at different values of the lowest positive correlations $(\mathrm{R}=.03, .06, .08, .09)$ are above zero and statistically significant $(p<.01)$, except the correlation between 
introjected regulation and the use of SSTs, indicate that the relationships between predictors and the criterion-the use of SSTs cannot be accounted for by CMV. These findings attest that CMV only had a marginal effect on the relationships between predictors and the criterion.

\subsection{Testing the Mediating Effect of Self-Determined Motivation}

The assumptions of normality, linearity, multicollinearity and homoscedasticity were tested. The skewness ( -.84 to -.22$)$ and kurtosis ( -.36 to .44$)$ values were between -2.0 and +2.0 (Balanda \& Macgillivray, 1988). Linearity was checked using partial regression plot analysis (Bray \& Maxwell, 1985). All plotted graphs were visually inspected, and no curvilinear or other non-linear relationships were found between the dependent and independent variables. The VIF values of the independent variables in the current study ranged from 1.23 to 2.86, which was well below the minimum cut-off level of 4.0 (Rud, 2000). Homoscedasticity of variance was tested using Levene's tests (Bray \& Maxwell, 1985). None of these nonmetric variables had more than two problematic metric variables (Hair et al., 2006). The mediating effect of self-determined motivation was then analysed with the bootstrapping method (Preacher \& Hayes, 2008). In this process, 1000 samples were bootstrapped using the PROCESS program with a 95\% confidence interval (Hayes, 2012).

As shown in Table 1, self-determined motivation did not significantly mediate the relationship between perceived control and the use of SSTs. Thus, H1 was not supported. However, self-determined motivation significantly mediated the relationship between ease of use and the use of SSTs $(b=.0262$, CIs $95 \% .0036$ $-.0530)$ and the relationship between usefulness and the use of SSTs $(b=.0162$, CIs $95 \% .0011-.384)$. Thus, $\mathrm{H} 2$ and $\mathrm{H} 3$ were supported.

\section{Discussion}

SDT has been widely used to explain human motivation and behavior, e.g. Halvari et al. (2010), Techatassanasoontorn and Tanvisuth (2008) and Leung and

Table 1. The mediating effect of self-determined motivation on the relationship between perceived control, ease of use, usefulness and the use of SSTs.

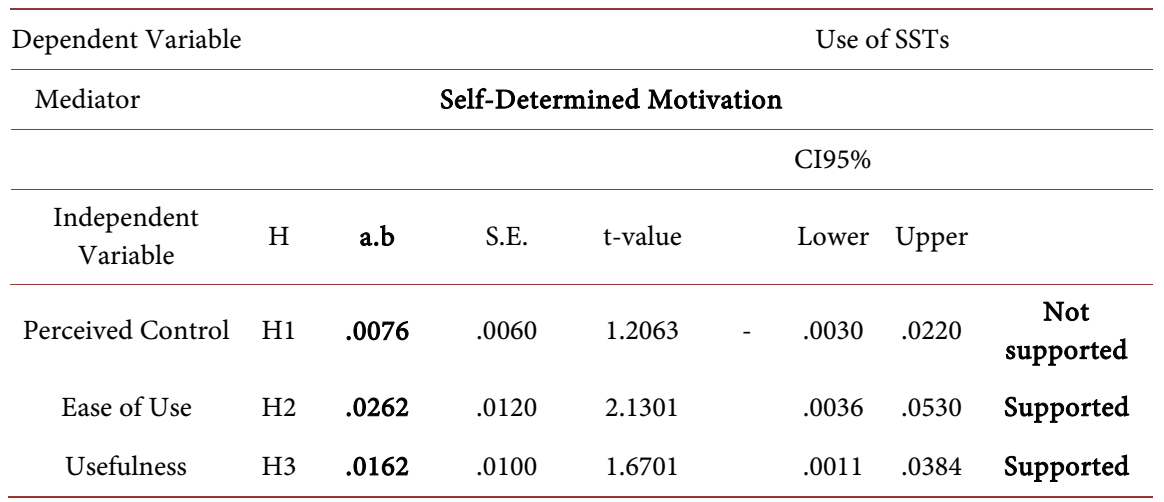

CI 95\% - 95\% Confidence Interval a.b-Indirect effect, H-hypotheses. 
Matanda (2013). SDT proposes that volitional forms of motivation are important, because they enhance human-activity engagement (Deci \& Ryan, 2000a). Autonomy, competence and relatedness are proposed as basic human needs that foster volitional forms of motivation. Previous studies have paid limited attention to the dimensions of basic human needs. Hence, the current study attempts to extend the dimensions of basic human needs set by SDT.

Consistent with the prediction based on Jaasma and Koper (1999), Sargeant and Lee (2004), Techatassanasoontorn and Tanvisuth (2008) and Leung and Matanda (2013), self-determined motivation mediated the relationship between ease of use and the use of SSTs. Self-determined motivation also mediated the relationship between usefulness and the use of SSTs, which is consistent with the prediction based on Meuter et al. (2005), Techatassanasoontorn and Tanvisuth (2008) and Leung and Matanda (2013). Contrary to the prediction based on Collier and Sherrell (2010), Techatassanasoontorn and Tanvisuth (2008) and Leung and Matanda (2013), self-determined motivation did not mediate the relationship between perceived control and the use of SSTs. These results indicate that ease of use and usefulness can nurture volitional forms of motivation, hence the use of SST. In conclusion, ease of use and usefulness can also be considered as basic human needs in the SST context. Because perceived control did not enhance the use of SSTs through self-determined motivation, it is not considered a basic human need in this context.

Perceived control, ease of use and usefulness were shown to enhance intrinsic motivation to use SSTs (Collier \& Sherrell, 2010; Jaasma \& Koper, 1999; Sargeant \& Lee, 2004; Meuter et al., 2005). The results indicate that ease of use and usefulness foster volitional forms of motivation. Ease of use has a close link with competence/self-efficacy (Dabholkar \& Bagozzi, 2002). Competence is a form of basic human need that nurtures volitional forms of motivation. Therefore, as expected, ease of use also fosters volitional forms of motivation.

Moreover, usefulness is shown to foster volitional forms of motivation, but its links with autonomy, competence and relatedness are not clear. This finding reveals a drawback in the SDT framework and also indicates a necessity to review the dimensions of basic human needs, at least in the SST context. These findings further suggest that basic human needs are not limited to autonomy, competence and relatedness.

Additionally, perceived control does not foster volitional forms of motivation, although it appears to have a similar concept to autonomy. One plausible explanation is that customized options offered to customers (perceived control) may not create autonomous contexts, because they may still feel pressure to use SST because of the presence of other customers and/or long queues at service counters. This suggests that autonomous contexts may be created only if customers have freedom/autonomy to choose to use SST to complete their transactions (Leung \& Matanda, 2013).

In addition to autonomy, competence and relatedness, retail managers can enhance the perceived usefulness of SSTs in customers, e.g. faster transactions or 
shortened queues, to foster volitional forms of motivation. Managers can also simplify steps for customers to complete transactions in order to enhance the perceived ease of use of SSTs to further enhance volitional forms of motivation in customers. As volitional forms of motivation are fostered, managers can deploy SSTs in mutually beneficial and cost-effective ways. Customers can feel more satisfied using SSTs when an internalization process is facilitated, while managers can offer minimal external incentives, e.g. coupons or discounts, to encourage customers to use SSTs. Furthermore, enhancing customized options of SSTs is insufficient to facilitate an internalization process. Therefore, service counters need to be provided so that autonomous contexts can be created for customers to choose to use SSTs.

\section{Limitations and Future Research}

Whilst the current study offers insights into the dimensions of basic human needs, it is subject to some limitations. The current study could be expanded to other contexts or countries, as consumer behavior may be different in different contexts (Arnould \& Thompson, 2005; De Mooij, 2010). As autonomy, competence and relatedness are considered sole basic human needs that drive students' motivations and school performances (Deci, Koestner, \& Ryan, 1999; Vallerand et al., 1992, 1993; Fortier, Vallerand, \& Guay, 1995), it is meaningful to investigate the effect of perceived ease of use and usefulness on students' motivations and school performances when using technology becomes more popular in educational contexts. The current study did not investigate the effects of situational factors, such as waiting time and queue length, or other moderators, such as age, gender differences. Examining these factors in future research could provide additional insight into the possible moderating effects of situational factors and their effects on the model.

\section{Conflicts of Interest}

The author declares no conflicts of interest regarding the publication of this paper.

\section{References}

Anderson, J. C., \& Gerbing, D. W. (1988). Structural Equation Modeling in Practice: A Review and Recommended Two-Step Approach. Psychological Bulletin, 103, 411. https://doi.org/10.1037/0033-2909.103.3.411

Arnould, E. J., \& Thompson, C. J. (2005). Consumer Culture Theory (CCT): Twenty Years of Research. Journal of Consumer Research, 31, 868-882. https://doi.org/10.1086/426626

Balanda, K. P., \& MacGillivray, H. L. (1988). Kurtosis: A Critical Review. The American Statistician, 42, 111-119. https://doi.org/10.1080/00031305.1988.10475539

Bandura, A. (1997). Self-Efficacy: The Exercise of Control. New York: Freeman.

Batra, R., \& Sinha, I. (2000). Consumer-Level Factors Moderating the Success of Private Label Brands. Journal of Retailing, 76, 175-191. 
https://doi.org/10.1016/S0022-4359(00)00027-0

Bray, J. H., \& Maxwell, S. E. (1985). Multivariate Analysis of Variance (Vol. 54). Thousand Oaks, CA: Sage. https://doi.org/10.4135/9781412985222

Bruner, G. C., \& Kumar, A. (2005). Applying TAM to Consumer Usage of Handheld Internet Devices. Journal of Business Research, 58, 553-558.

https://doi.org/10.1016/j.jbusres.2003.08.002

Burns, A. C., \& Bush, R. F. (2006). Marketing Research (5th ed.). Upper Saddle River, NJ: Prentice Hall.

Collier, J. E., \& Sherrell, D. L. (2010). Examining the Influence of Control and Convenience in a Self-Service Setting. Journal of the Academy of Marketing Science, 38, 490-509. https://doi.org/10.1007/s11747-009-0179-4

Curran, J. M., \& Meuter, M. L. (2005). Self-Service Technology Adoption: Comparing Three Technologies. Journal of Services Marketing, 19, 103-113. https://doi.org/10.1108/08876040510591411

Dabholkar, P. A. (1996). Consumer Evaluations of New Technology-Based Self-Service Options: An Investigation of Alternative Models of Service Quality. International Journal of Research in Marketing, 13, 29-51. https://doi.org/10.1016/0167-8116(95)00027-5

Dabholkar, P. A., \& Bagozzi, R. P. (2002). An Attitudinal Model of Technology-Based Self-Service: Moderating Effects of Consumer Traits and Situational Factors. Journal of the Academy of Marketing Science, 30, 184-201. https://doi.org/10.1177/0092070302303001

Davis, F. D. (1986). A Technology Acceptance Model for Empirically Testing New End-User Information Systems: Theory and Results. PhD Thesis, Cambridge, MA: Massachusetts Institute of Technology, Sloan School of Management.

De Mooij, M. (2010). Consumer Behavior and Culture: Consequences for Global Marketing and Advertising. Thousand Oaks, CA: Sage.

Deci, E. L., \& Ryan, R. M. (1985). Self-Determination. Hoboken, NJ: John Wiley \& Sons, Inc.

Deci, E. L., \& Ryan, R. M. (1991). A Motivational Approach to Self: Integration in Personality. In R. Dienstbier (Ed.), Nebraska Symposium on Motivation: Vol. 38, Perspectives on Motivation (pp. 237-288). Lincoln, NE: University of Nebraska Press.

Deci, E. L., \& Ryan, R. M. (2000a). Self-Determination Theory and the Facilitation of Intrinsic Motivation, Social Development, and Well-Being. American Psychologist, 55, 68-78. https://doi.org/10.1037//0003-066X.55.1.68

Deci, E. L., \& Ryan, R. M. (2000b). Intrinsic and Extrinsic Motivations: Classic Definitions and New Directions. Contemporary Educational Psychology, 25, 54-67. https://doi.org/10.1006/ceps.1999.1020

Deci, E. L., \& Ryan, R. M. (2008). Facilitating Optimal Motivation and Psychological Well-Being across Life's Domains. Canadian Psychology, 49, 14-23.

https://doi.org/10.1037/0708-5591.49.1.14

Deci, E. L., \& Ryan, R. M. (2012). Self-Determination Theory. In P. A. M. Van Lange, A. W. Kruglanski, \& E. T. Higgins (Eds.), Handbook of Theories of Social Psychology (pp. 416-437, Vol. 1). Thousand Oaks, CA: Sage. https://doi.org/10.4135/9781446249215.n21

Deci, E. L., Eghrari, H., Patrick, B. C., \& Leone, D. R. (1994). Facilitating Internalization: The Self-Determination Theory Perspective. Journal of Personality, 62, 119-142. https://doi.org/10.1111/j.1467-6494.1994.tb00797.x 
Deci, E. L., Koestner, R., \& Ryan, R. M. (1999). A Meta-Analytic Review of Experiments Examining the Effects of Extrinsic Rewards on Intrinsic Motivation. Psychological Bulletin, 125, 627-668. https://doi.org/10.1037/0033-2909.125.6.627

Eriksson, K., \& Nilsson, D. (2007). Determinants of the Continued Use of Self-Service Technology: The Case of Internet Banking. Technovation, 27, 159-167. https://doi.org/10.1016/j.technovation.2006.11.001

Eriksson, K., Bagozzi, R. P., \& Warshaw, P. R. (2001). Customer Acceptance of Internet Banking in Estonia. International Journal of Bank Marketing, 23, 200-216. https://doi.org/10.1108/02652320510584412

Farrell, A. M., \& Rudd, J. M. (2009). Factor Analysis and Discriminant Validity: A Brief Review of Some Practical Issues. In D. Tojib (Ed.), Australia-New Zealand Marketing Academy Conference. Australia-New Zealand Marketing Academy.

Fernet, C. (2011). Development and Validation of the Work Role Motivation Scale for School Principals (WRMS-SP). Educational Administration Quarterly, 47, 307-331. https://doi.org/10.1177/0013161X10385108

Field, A. (2000). Discovering Statistics Using SPSS for Windows. Thousand Oaks, CA: Sage Publications.

Fornell, C., \& Larcker, D. F. (1981). Evaluating Structural Equation Models with Unobservable Variables and Measurement Error. Journal of Marketing Research, 18, 39-50. https://doi.org/10.1177/002224378101800104

Fortier, M. S., Vallerand, R. J., \& Guay, F. (1995). Academic Motivation and School Performance: Toward a Structural Model. Contemporary Educational Psychology, 20, 257-274. https://doi.org/10.1006/ceps.1995.1017

Gagne, M., \& Deci, E. L. (2005). Self-Determination Theory and Work Motivation. Journal of Organizational Behavior, 26, 331-362. https://doi.org/10.1002/job.322

Gallaugher, J. (2010). Information Systems: A Manager's Guide to Harnessing Technology. Boston, MA: Flat World Knowledge.

Guriting, P., \& Ndubisi, N. O. (2006). Borne Online Banking: Evaluating Customer Perceptions and Behavioral Intention. Management Research News, 29, 6-15. https://doi.org/10.1108/01409170610645402

Guttman, L. (1954). A New Approach to Factor Analysis: The Radex. In P. F. Lazarsfeld (Ed.), Mathematical Thinking in the Social Sciences (pp. 258-348). New York: Free Press.

Hair, J. F., Black, W. C., Babin, B. J., \& Anderson, R. E. (2006). Multivariate Data Analysis: A Global Perspective. New Jersey: Prentice Hall.

Hair, J. F., Black, W. C., Babin, B. J., \& Anderson, R. E. (2010). Multivariate Data Analysis (7th ed.). Englewood Cliffs, NJ: Prentice Hall.

Haladyna, T. M. (1999). A Complete Guide to Student Grading. Boston, MA: Allyn and Bacon.

Halvari, A. E. M., Halvari, H., Bjørnebekk, G., \& Deci, E. L. (2010). Motivation and Anxiety for Dental Treatment: Testing a Self-Determination Theory Model of Oral Self-Care Behavior and Dental Clinic Attendance. Motivation and Emotion, 34, 15-33. https://doi.org/10.1007/s11031-010-9154-0

Hattie, J. (1985). Methodology Review: Assessing Unidimensionality of Tests and Items. Applied Psychological Measurement, 9, 139-164. https://doi.org/10.1177/014662168500900204

Hayes, A. F. (2012). Process: A Versatile Computational Tool for Observed Variable Mediation, Moderation, and Conditional Process Modeling. 
Hernan-dez, J. M. C., \& Mazzon, J. A. (2007). Adoption of Internet Banking: Proposition and Implementation of an Integrated Methodology Approach. International Journal of Bank Marketing, 25, 72-88. https://doi.org/10.1108/02652320710728410

Jaasma, M. A., \& Koper, R. J. (1999). The Relationship of Student-Faculty Out-of-Class Communication to Instructor Immediacy and Trust and to Student Motivation. Communication Education, 48, 41-47. https://doi.org/10.1080/03634529909379151

Jaruwachirathanakul, B., \& Fink, D. (2005). Internet Banking Adoption Strategies for a Developing Country: The Case of Thailand. Internet Research, 15, 295-311. https://doi.org/10.1108/10662240510602708

Judd, C. M., \& Kenny, D. A. (2010). Data Analysis in Social Psychology: Recent and Recurring Issues. Hoboken, NJ: John Wiley \& Sons, Inc. https://doi.org/10.1002/9780470561119.socpsy001004

Kelly, P., Lawlor, J., \& Mulvey, M. (2010). A Review of Key Factors Affecting the Adoption of Self-Service Technologies in Tourism.

Kim, Y. J., Chun, J. U., \& Song, J. (2009). Investigating the Role of Attitude in Technology Acceptance from an Attitude Strength Perspective. International Journal of Information Management, 29, 67-77. https://doi.org/10.1016/j.ijinfomgt.2008.01.011

Laforet, S., \& Li, X. (2005). Consumers' Attitudes towards Online and Mobile Banking in China. International Journal of Bank Marketing, 23, 362-380. https://doi.org/10.1108/02652320510629250

Lanseng, E. J., \& Andreassen, T. W. (2007). Electronic Healthcare: A Study of People's Readiness and Attitude toward Performing Self-Diagnosis. International Journal of Service Industry Management, 18, 394-417. https://doi.org/10.1108/09564230710778155

Lee, W., Castellanos, C., \& Choi, C. H. S. (2012). The Effect of Technology Readiness on Customers' Attitudes toward Self-Service Technology and Its Adoption; the Empirical Study of US Airline Self-Service Check-In Kiosks. Journal of Travel \& Tourism Marketing, 29, 731-743. https://doi.org/10.1080/10548408.2012.730934

Leung, L. S. K., \& Matanda, M. J. (2013). The Impact of Basic Human Needs on the Use of Retailing Self-Service Technologies: A Study of Self-Determination Theory. Journal of Retailing and Consumer Services, 20, 549-559. https://doi.org/10.1016/j.jretconser.2013.06.003

Li, F., \& Harmer, P. (1996). Testing the Simplex Assumption Underlying the Sport Motivation Scale: A Structural Equation Modeling Analysis. Research Quarterly for Exercise and Sport, 67, 396-405. https://doi.org/10.1080/02701367.1996.10607971

Liao, Z., \& Cheung, M. T. (2002). Internet-Based e-Banking and Consumer Attitudes: An Empirical Study. Information and Management Archive, 39, 283-295. https://doi.org/10.1016/S0378-7206(01)00097-0

Lin, J. S. C., \& Chang, H. C. (2011). The Role of Technology Readiness in Self-Service Technology Acceptance. Managing Service Quality, 21, 424-444. https://doi.org/10.1108/09604521111146289

Lindell, M. K., \& Whitney, D. J. (2001). Accounting for Common Method Variance in Cross-Sectional Research Designs. Journal of Applied Psychology, 86, 114-121. https://doi.org/10.1037/0021-9010.86.1.114

MacKinnon, D. P., \& Luecken, L. J. (2008). How and for Whom? Mediation and Moderation in Health Psychology. Health Psychology, 27, S99. https://doi.org/10.1037/0278-6133.27.2(Suppl.).S99

MacKinnon, D. P., Lockwood, C. M., Hoffman, J. M., West, S. G., \& Sheets, V. (2002). A 
Comparison of Methods to Test Mediation and Other Intervening Variable Effects. Psychological Methods, 7, 83. https://doi.org/10.1037/1082-989X.7.1.83

Malhotra, N. K. (2006). Marketing Research-An Applied Orientation (5th ed.). Upper Saddle River, NJ: Prentice Hall.

Meuter, M. L., Bitner, M. J., Ostrom, A. L., \& Brown, S. W. (2005). Choosing among Alternative Service Delivery Modes: An Investigation of Customer Trial of Self-Service Technologies. Journal of Marketing, 69, 61-83.

https://doi.org/10.1509/jmkg.69.2.61.60759

Meuter, M. L., Ostrom, A. L., Roundtree, R. I., \& Bitner, M. J. (2000). Self-Service Technologies: Understanding Customer Satisfaction with Technology-Based Service Encounters. Journal of Marketing, 64, 50-64. https://doi.org/10.1509/jmkg.64.3.50.18024

Mumani, A., Stone, R., \& Wang, Z. (2018). The Effect of Scanning Technology and UPC Placement on Supermarket Self-Checkout. Packaging Technology and Science, 31, 83-96. https://doi.org/10.1002/pts.2355

Parasuraman, A. (2000). Technology Readiness Index (TRI): A Multiple-Item Scale to Measure Readiness to Embrace New Technologies. Journal of Service Research, 2, 307-320. https://doi.org/10.1177/109467050024001

Parasuraman, P., Zeithaml, V., \& Malhotra, A. (2005). E-SERVQUAL: A Multiple-Item Scale for Assessing Electronic Service Quality. Journal of Service Research, 7, 213-233. https://doi.org/10.1177/1094670504271156

Parham, D., Roberts, P., \& Sun, H. (2001). Information Technology and Australia's Productivity Surge. https://doi.org/10.2139/ssrn.287799

Polatoglu, V. N., \& Ekin, S. (2001). An Empirical Investigation of the Turkish Consumers' Acceptance of Internet Banking Services. International Journal of Bank Marketing, 19, 156-165. https://doi.org/10.1108/02652320110392527

Preacher, K. J., \& Hayes, A. F. (2008). Asymptotic and Resampling Strategies for Assessing and Comparing Indirect Effects in Multiple Mediator Models. Behavior Research Methods, 40, 879-891. https://doi.org/10.3758/BRM.40.3.879

Rangarajan, D., Falk, T., \& Schillewaert, N. (2007). Determinants and Outcomes of Customers' Use of Self-Service Technology in a Retail Setting. Journal of Service Research, 10, 3-21. https://doi.org/10.1177/1094670507302990

Rud, O. P. (2000). Data Mining Cookbook CD-Rom: Modeling Data for Marketing, Risk and Customer Relationship Management. Hoboken, NJ: John Wiley \& Sons, Inc.

Ryan, R. M. (1995). Psychological Needs and the Facilitation of Integrative Processes. Journal of Personality, 63, 397-427. https://doi.org/10.1111/j.1467-6494.1995.tb00501.x

Ryan, R. M., \& Connell, J. P. (1989). Perceived Locus of Causality and Internalization: Examining Reasons for Acting in Two Domains. Journal of Personality and Social Psychology, 57, 749. https://doi.org/10.1037/0022-3514.57.5.749

Sargeant, A., \& Lee, S. (2004). Trust and Relationship Commitment in the United Kingdom Voluntary Sector: Determinants of Donor Behavior. Psychology \& Marketing, 21, 613-635. https://doi.org/10.1002/mar.20021

Sharma, R., Yetton, P., \& Crawford, J. (2010). A Critique of the Marker Variable Technique: The Effect of Alternative Marker Variable Criteria. In European Conference on Information Systems (pp. 1-12).

Shrout, P. E., \& Bolger, N. (2002). Mediation in Experimental and Nonexperimental Studies: New Procedures and Recommendations. Psychological Methods, 7, 422.

https://doi.org/10.1037/1082-989X.7.4.422 
Steenkamp, J. B. E., \& Van Trijp, H. (1991). The Use of LISREL in Validating Marketing Constructs. International Journal of Research in Marketing, 8, 283-299. https://doi.org/10.1016/0167-8116(91)90027-5

Taillon, B. J., \& Huhmann, B. A. (2019). Strategic Consequences of Self-Service Technology Evaluations. Journal of Strategic Marketing, 27, 268-279. https://doi.org/10.1080/0965254X.2017.1411387

Techatassanasoontorn, A. A., \& Tanvisuth, A. (2008). The Integrated Self-Determination and Self-Efficacy Theories of ICT Training and Use: The Case of the Socio-Economically Disadvantaged. GlobDev 2008, 19.

Teixeira, P. J., Carraça, E. V., Markland, D., Silva, M. N., \& Ryan, R. M. (2012). Exercise, Physical Activity, and Self-Determination Theory: A Systematic Review. International Journal of Behavioral Nutrition and Physical Activity, 9, 78.

https://doi.org/10.1186/1479-5868-9-78

Vallerand, R. J., Pelletier, L. G., Blais, M. R., Briere, N. M., Senecal, C., \& Vallieres, E. F. (1992). The Academic Motivation Scale: A Measure of Intrinsic, Extrinsic and a Motivation in Education. Educational and Psychological Measurement, 52, 1003-1017. https://doi.org/10.1177/0013164492052004025

Vallerand, R. J., Pelletier, L. G., Blais, M. R., Briere, N. M., Senecal, C., \& Vallieres, E. F. (1993). On the Assessment of Intrinsic, Extrinsic and a Motivation in Education: Evidence of Concurrent and Construct Validity of the Academic Motivation Scale. Educational and Psychological Measurement, 53, 159-172. https://doi.org/10.1177/0013164493053001018

Vargo, S. L., \& Lusch, R. F. (2004). Evolving to a New Dominant Logic for Marketing. Journal of Marketing, 68, 1-17. https://doi.org/10.1509/jmkg.68.1.1.24036

Venkatesh, V. (2000). Determinants of Perceived Ease of Use: Integrating Control, Intrinsic Motivation, and Emotion into the Technology Acceptance Model. Information Systems Research, 11, 342-365. https://doi.org/10.1287/isre.11.4.342.11872

Venkatesh, V., \& Davis, F. D. (2000). A Theoretical Extension of the Technology Acceptance Model: Four Longitudinal Field Studies. Management Science, 46, 186-204. https://doi.org/10.1287/mnsc.46.2.186.11926

Wang, J., \& Namen, J. (2004). Adoption of Technology-Based Self-Service: A Case Study on Airport Self Check-In Service. Master's Thesis, Lulea: University of Lulea.

Wang, Y. S., Wang, Y. M., Lin, H. H., \& Tang, T. I. (2003). Determinants of User Acceptance of Internet Banking: An Empirical Study. International Journal of Service Industry Management, 14, 501-519. https://doi.org/10.1108/09564230310500192

Weijters, B., Rangarajan, D., \& Falk, T. (2005). Customers' Usage of Self Service Technology a Retail Setting (p. 19). Vlerick Leuven Gent Working Paper.

Xie, L., Shen, W., \& Zheng, Y. (2011). Examining the Effect of Service Experiences on the Attitude towards and Intention on Using Self-Service Technology. In International Conference on Computer Science and Service System (pp. 2233-2240). New York: Institute of Electrical and Electronics Engineers.

Yang, J., \& Klassen, K. J. (2008). How Financial Markets Reflect the Benefits of Self-Service Technologies. Journal of Enterprise Information Management, 21, 448-467.

https://doi.org/10.1108/17410390810904238

Yen, R., \& Gwinner, K. P. (2003). Internet Retail Customer Loyalty: The Mediating Role of Relational Benefits. International Journal of Service Industry Management, 14, 483-500. https://doi.org/10.1108/09564230310500183

Zeithaml, V., Parasuraman, A., \& Malhotra, A. (2002). Service Quality Delivery through 
Websites: A Critical Review of Extant Knowledge. Journal of the Academy of Marketing Science, 30, 362-375. https://doi.org/10.1177/009207002236911

Zhao, X., Lynch, J. G., \& Chen, Q. (2010). Reconsidering Baron and Kenny: Myths and Truths about Mediation Analysis. Journal of Consumer Research, 37, 197-206. https://doi.org/10.1086/651257

Zhao, X., Mattila, A. S., \& Tao, L. S. E. (2008). The Role of Post-Training Self-Efficacy in Customers' Use of Self Service Technologies. International Journal of Service Industry Management, 19, 492-505. https://doi.org/10.1108/09564230810891923

Zheng, Z. K. (2006). Innovation, Imitation, and New Product Performance: The Case of China. Industrial Marketing Management, 35, 394-402.

https://doi.org/10.1016/j.indmarman.2005.10.006

Zhu, Z. (2002). Fix It or Leave It: Antecedents and Consequences of Perceived Control in Technology-Based Self-Service Failure Encounters. Doctoral Dissertation, Chicago, IL: University of Illinois. 


\section{Appendix A}

Correlation Matrix $(\mathrm{N}=361)$

\begin{tabular}{|c|c|c|c|c|c|c|c|c|c|c|}
\hline Constructs & 1 & & 2 & 3 & & 4 & 5 & 6 & 7 & 8 \\
\hline \multicolumn{11}{|l|}{ 1. Perceived Control } \\
\hline 2. Ease of Use & $.47^{* *}$ & & & & & & & & & \\
\hline 3. Usefulness & $.52^{* *}$ & & $.42^{* *}$ & & & & & & & \\
\hline 4. Use Of SSTs & $.70^{* *}$ & & $.56^{* *}$ & $.65^{* *}$ & & & & & & \\
\hline 5. External Regulation & $.31^{* *}$ & - & .04 & $.18^{* *}$ & & $.14^{*}$ & & & & \\
\hline 6. Introjected Regulation & $.21^{* *}$ & - & $.24^{* *}$ & .03 & - & .03 & $.35^{* *}$ & & & \\
\hline 7. Integrated Regulation & $.69^{* *}$ & & $.53^{* *}$ & $.60^{\star *}$ & & $.71^{\star *}$ & $.32^{* *}$ & $.21^{\star *}$ & & \\
\hline 8. Intrinsic Regulation & $.67^{* *}$ & & $.56^{* *}$ & $.60^{\star *}$ & & $.84^{* *}$ & $.29^{* *}$ & .09 & $.80^{\star \star}$ & \\
\hline Mean & 12.74 & & 14.62 & 14.95 & & 14.61 & 12.29 & 7.51 & 12.01 & 12.97 \\
\hline SD & 4.14 & & 4.37 & 4.03 & & 4.45 & 3.76 & 3.86 & 4.8 & 4.49 \\
\hline Composite Reliability & .89 & & .92 & .91 & & .95 & .73 & .9 & .92 & .97 \\
\hline AVE & .72 & & .79 & .77 & & .87 & .47 & .76 & .79 & .9 \\
\hline Square root of AVE & .85 & & .89 & .88 & & .93 & .69 & .87 & .89 & .95 \\
\hline
\end{tabular}

Notes: Sample size $=361,{ }^{* *} p<.01,{ }^{*} p<.05$.

\section{Appendix B}

Demographic Profile of Respondents $(\mathrm{N}=361)$

\begin{tabular}{ccc}
\hline Gender & & $\mathrm{N}$ \\
\hline Female & $51 \%$ & 184 \\
Male & $49 \%$ & 177 \\
Age & & \\
$19-20$ & $4 \%$ & 14 \\
$21-30$ & $21 \%$ & 76 \\
$31-46$ & $26 \%$ & 94 \\
$47-55$ & $17 \%$ & 61 \\
$56-65$ & $21 \%$ & 76 \\
Over 66 & $11 \%$ & 40 \\
Income & & \\
20,000 and under & $14 \%$ & 51 \\
$20,001-40,000$ & $25 \%$ & 90 \\
$40,001-60,000$ & $21 \%$ & 76 \\
$60,001-80,000$ & $13 \%$ & 47 \\
$80,001-100,000$ & $10 \%$ & 36 \\
$100,001-150,000$ & $12 \%$ & 43 \\
\hline
\end{tabular}




\section{Continued}

\begin{tabular}{ccc}
\hline Over 150,000 & $5 \%$ & 18 \\
Education Level & & 51 \\
Secondary (Year 7 - 10) & $14 \%$ & 79 \\
High School (Year 11 - 12) & $22 \%$ & 112 \\
TAFE/Commercial Institutes/Diplomas & $31 \%$ & 79 \\
Bachelor Degree & $22 \%$ & 32 \\
Post Graduate Level & $9 \%$ & 8 \\
PhD and above & $2 \%$ & \\
Ethnic Background & & 199 \\
Australian & $55 \%$ & 101 \\
European & $28 \%$ & 11 \\
Asian & $3 \%$ & 7 \\
African & $2 \%$ & 4 \\
New Zealander & $1 \%$ & 4 \\
Russian & $1 \%$ & 4 \\
Torres Strait & $1 \%$ & \\
\hline & & 4 \\
\hline
\end{tabular}

